This item was submitted to Loughborough's Research Repository by the author.

Items in Figshare are protected by copyright, with all rights reserved, unless otherwise indicated.

\title{
New routes towards reutericyclin analogues
}

PLEASE CITE THE PUBLISHED VERSION

http://dx.doi.org/10.1039/c3cc47867j

\section{PUBLISHER}

(c) Royal Society of Chemistry

\section{VERSION}

SMUR (Submitted Manuscript Under Review)

\section{PUBLISHER STATEMENT}

This work is made available according to the conditions of the Creative Commons Attribution-NonCommercialNoDerivatives 4.0 International (CC BY-NC-ND 4.0) licence. Full details of this licence are available at: https://creativecommons.org/licenses/by-nc-nd/4.0/

\section{LICENCE}

CC BY-NC-ND 4.0

\section{REPOSITORY RECORD}

Jones, Raymond C.F., James P. Bullous, Ching-Man Law, and Mark R.J. Elsegood. 2019. "New Routes Towards Reutericyclin Analogues". figshare. https://hdl.handle.net/2134/18335. 


\title{
New Routes towards Reutericyclin Analogues
}

\author{
Raymond C F Jones, ${ }^{a}{ }^{*}$ James P Bullous, $^{a}$ Carole C M Law ${ }^{\mathrm{a}}$ and Mark R J Elsegood ${ }^{\mathrm{a}}$ \\ Received (in $X X X, X X X) X$ th $X X X X X X X X X 20 X X$, Accepted Xth $X X X X X X X X X 20 X X$ \\ DOI: $10.1039 / b 000000 x$
}

5 A range of $\mathrm{N}$-acylpyrrolo[3,4-c]isoxazoles and derived $\mathrm{N}$ acyltetramides has been prepared via a nitrile oxide dipolar cycloaddition approach, as analogues of the acyltetramic acid metabolite reutericyclin, of interest for their antibiotic potential against Gram-positive bacteria including hospital10 acquired infections of resistant Clostridium difficile.

In order to combat the growing resistance to generally administered antibiotics, such as penicillin and methicillin, the research community is endeavouring to find new compounds that actively inhibit problematic resistant bacteria. ${ }^{1}$ This effort has 15 identified a number of potential candidates, one example of which is reutericyclin (1), isolated in 2000 by Jung et al. from Lactobacillius reuteri LTH2584. ${ }^{2}$ Reutericyclin belongs to the 3acyltetramic acid group of natural products (2), characterised by a pyrrolidine-2,4-dione unit carrying an acyl group at C-3. ${ }^{3}$ 20 Molecules containing this motif exhibit a range of bio-activities including antibiotic, antitumor, antiviral, antiulcerative, fungicidal and cytotoxic properties. ${ }^{4}$ Interest in the antibiotic activity of tetramic acids has recently been stimulated by their key relationship to the inducers of bacterial quorum sensing. ${ }^{5}$

${ }_{25}$ Reutericyclin and derivatives display varying inhibition in Grampositive bacteria. ${ }^{2,6}$ The most interesting of these results is the inhibition of growth of resistant bacterium Clostridium difficile, a leading cause of antibiotic-associated diarrhoea in hospitalized patients which can lead to mortalities in persons with a зо compromised immune system. ${ }^{7}$
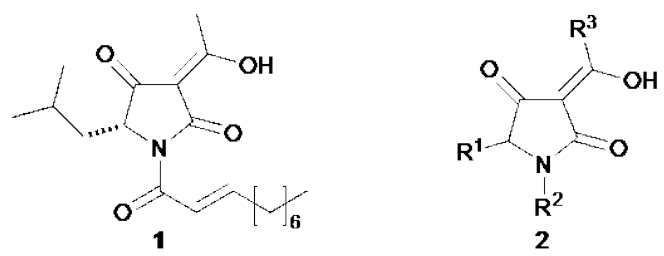

We have, over many years, explored the synthesis of the acyltetramic acid moiety ${ }^{8}$ and other cyclic tricarbonyl systems, ${ }^{9}$ most recently using pyrroloisoxazoles as masked acyltetramic 35 acids and as core building blocks for peripheral elaboration. ${ }^{10,11}$ Our $2^{\text {nd }}$ generation strategy (Scheme 1$)^{10}$ uses pyrrolo[3,4c]isoxazoles 3 (cf. pyrrolo[3,4- $d$ ] isoxazoles in our $1^{\text {st }}$ generation approach $^{11}$ ) formed by cycloaddition of nitrile oxides 4 , available in three steps from $\alpha$-amino esters, with enamino ester ${ }_{40}$ dipolarophiles. We report here significant practical improvements in this strategy (principally in lactam closure) and its application to access novel bicyclic reutericyclin analogues. Reutericyclin has $R$-configuration at $\mathrm{C}-5$, and is presumably biosynthesised from $R$-leucine, ${ }^{3,12}$ however we have conducted our studies in the 45 more readily available $S$-series: the chemistry should, of course, be equally applicable to the enantiomeric series. ${ }^{13}$

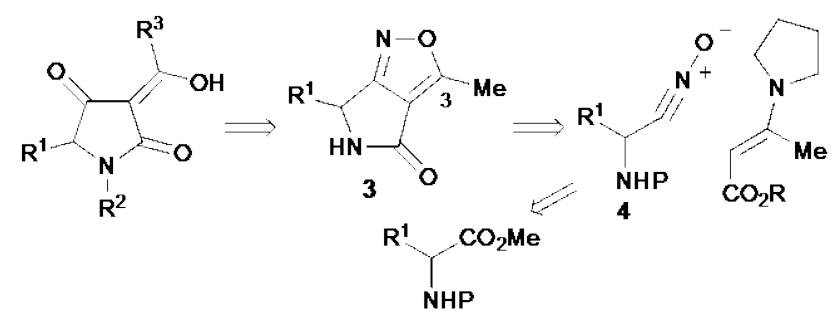

Scheme 1. The pyrrolo[3,4-c]isoxazole strategy ( $\mathrm{P}=$ protecting group)

The commercially available methyl esters of $S$-valine, $S$ 50 leucine and $S$-phenylglycine were efficiently $\mathrm{N}$-protected $\left(\mathrm{Boc}_{2} \mathrm{O}\right.$, $\mathrm{Et}_{3} \mathrm{~N}, \mathrm{CH}_{2} \mathrm{Cl}_{2}, 0-20{ }^{\circ} \mathrm{C}$; 99, 97 and 99\%, respectively). The protected amino esters (5a-c, respectively) were selectively reduced to the corresponding aldehydes using DIBAL- $\mathrm{H}$ at -78 ${ }^{\circ} \mathrm{C}$ (91, 93 and 87\%), which were converted directly to the oximes ${ }_{55}$ 6a-c $\left(\mathrm{H}_{2} \mathrm{NOH} . \mathrm{HCl}, \mathrm{NaOAc}\right.$, aq. EtOH, 2-8 ${ }^{\circ} \mathrm{C}$; 86, 79 and 88\%) to inhibit potential epimerisation (Scheme 2). Treatment with NCS $\left(\mathrm{CHCl}_{3}\right.$ reflux) afforded C-chloro-oximes 7 , either used directly (7a,c) or isolated (7b; 75\%); an extended reaction time for chlorination $(18 \mathrm{~h})$ led to better results when using the 60 hydroximoyl chlorides 7 (vide infra) than in our previous reports.

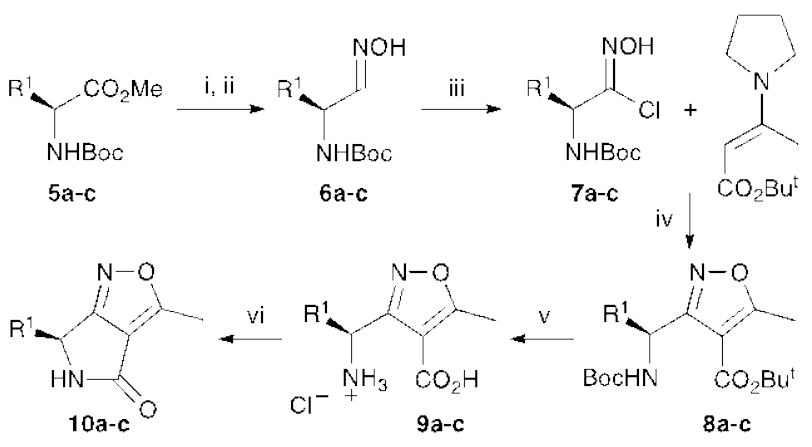

Scheme 2. Synthesis of pyrroloisoxazoles. 10. a, $\mathrm{R}^{1}=\mathrm{CHMe}_{2} ; \mathrm{b}, \mathrm{R}^{1}=$

$\mathrm{CH}_{2} \mathrm{CHMe}_{2}$; c, $\mathrm{R}^{1}=$ Ph. Reagents: i, DIBAL-H, toluene, $-78^{\circ} \mathrm{C}$; ii,

$\mathrm{H}_{2} \mathrm{NOH} . \mathrm{HCl}, \mathrm{NaOAc}$, aq. EtOH, $2-8{ }^{\circ} \mathrm{C}$; iii, NCS, $\mathrm{CHCl}_{3}$ reflux, $18 \mathrm{~h}$; iv, $65 \mathrm{Et}_{3} \mathrm{~N}, \mathrm{CHCl}_{3}$ reflux; v, TFA, $20^{\circ} \mathrm{C}$; $2 \mathrm{M}$ aq. $\mathrm{HCl}$; vi, T3P, EtOAc, $0-20^{\circ} \mathrm{C}$,

$17 \mathrm{~h}$ (with 9a,b) or PS-CDI, Et ${ }_{3} \mathrm{~N}, \mathrm{DMF}-\mathrm{CH}_{2} \mathrm{Cl}_{2}, 20^{\circ} \mathrm{C}, 17 \mathrm{~h}$ (with 9c)

The key dipolar cycloaddition step was performed by addition of $\mathrm{Et}_{3} \mathrm{~N}$ to the chloro-oximes in the presence of the pyrrolidine 
enamine of tert-butyl acetoacetate and pyrrolidine (separately prepared; toluene reflux, Dean-Stark conditions; 99\%) to form the nitrile oxide in situ and complete the cycloaddition $\left(\mathrm{CHCl}_{3}\right.$ reflux) to afford isoxazoles $\mathbf{8 a}, \mathbf{c}$ (49 and 56\% from $\mathbf{6 a}, \mathbf{c}$ ) and $\mathbf{8 b}$ 5 (60\% from $7 \mathbf{b})$. Simultaneous deprotection of the N-Boc amine and tert-butyl ester cleavage was achieved by acid treatment (TFA, $20^{\circ} \mathrm{C}$; then $2 \mathrm{M}$ aq. $\mathrm{HCl}$ to give hydrochloride salts of better stability for handling and on storage) to leave amino acid salts 9a-c (99, 70 and 68\%).

10 The final stage in assembly of the pyrroloisoxazoles, closure of the pyrrolo ring, was initially completed by our previously reported method using N-[3-(dimethylamino)propyl]-N'ethylcarbodiimide hydrochloride (EDCI) (N-hydroxysuccinimide, $\mathrm{Et}_{3} \mathrm{~N}, \mathrm{DMF}, 0-20^{\circ} \mathrm{C}$ ) which required column chromatography 15 and yielded the pyrroloisoxazoles 10a,b in unreliable yields (ranging 8-60\%). ${ }^{10 \mathrm{~b}}$ Other peptide coupling reagents were investigated: whilst PyBroP failed, HATU did produce 10a in $40 \%$ yield. ${ }^{14}$ The variable performance could be improved by using a polystyrene-supported carbodiimide (supplied as PS-CDI; 20 Argonaut Technologies $\left.{ }^{\mathrm{TM}}\right)\left(\mathrm{Et}_{3} \mathrm{~N}, \mathrm{DMF}-\mathrm{CH}_{2} \mathrm{Cl}_{2}, 20{ }^{\circ} \mathrm{C}, 17 \mathrm{~h}\right)$ that reliably afforded 10a (66\%), still however requiring column chromatographic purification and a costly alternative. Finally the simplest and most reliable lactam closure was achieved using the recently commercialised cyclic propylphosphonic anhydride 25 (supplied as T3P; Archemica $\left.{ }^{\mathrm{TM}}\right) .{ }^{15}$ Thus a base $\left(\mathrm{Et}_{3} \mathrm{~N}\right.$ ) was added to the salts 10a,b in EtOAc followed by T3P $\left(0-20^{\circ} \mathrm{C}, 17 \mathrm{~h}\right)$. The pyrroloisoxazoles 10a,b were isolated pure without needing chromatography in good yields (59 and 68\%). The phenylglycine-derived 10c was unsuccessful with T3P but could 30 be prepared reliably by the PS-CDI protocol (50\%). We have thus revealed two improved protocols for lactam closure to pyrroloisoxazoles 10: using T3P or PS-CDI.

The last stage in the synthesis of the masked reutericyclin analogues was to perform an $\mathrm{N}$-acylation. As base we selected to 35 use BuLi (THF, $-78^{\circ} \mathrm{C}$ ). Carboxylic esters were investigated as acylating agents but without success. However, acyl chlorides proved to be effective acylating agents to produce the $\mathrm{N}$-acyl derivatives 11 (Scheme 3). ${ }^{13} \mathrm{~A}$ variety of acyl chlorides were selected including long and short aliphatic chains, an $\alpha, \beta$ 40 unsaturated chain, a hindered branched moiety and an aromatic substituent, and all afforded N-acyl products $\mathbf{1 1}$ in yields of 33$97 \%$ (Table 1). $\dagger$ Longer chain, aromatic or more hindered acyl chlorides required a slightly longer time for complete reaction than the shorter, unhindered, examples; a standard reaction time 45 of $3 \mathrm{~h}$ was eventually employed. The constitution of the N-(but-2enyl)-6-(2-methylpropyl)pyrroloisoxazole 11c was confirmed by an X-ray crystal structure (Fig. 1). $\neq$

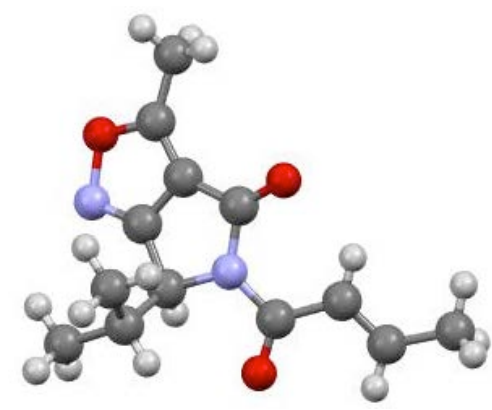

Figure 1. X-Ray crystal structure of $\mathrm{N}$-acyl pyrroloisoxazole 11c. $\mathrm{O}=$ red, $\mathrm{N}=$ Blue, $\mathrm{C}$ = grey, $\mathrm{H}$ = light gey.<smiles>[R1]C(=O)N1C(=O)c2c(noc2C)C1[Y11]</smiles>

Scheme 3. N-Acylation of pyrroloisoxazoles $\mathbf{1 0}$, see Table 1

Table 1. Masked reutericyclin analogues: N-acyl pyrroloisoxazoles 11<smiles>CC(=O)N1C(=O)c2c(noc2C)[C@H](C(C)C)N1C(=O)C[13CH3]</smiles>

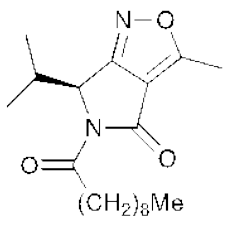<smiles>C=CC(=O)N1C(=O)c2c(noc2C)[C@H]1C(C)C</smiles><smiles></smiles>

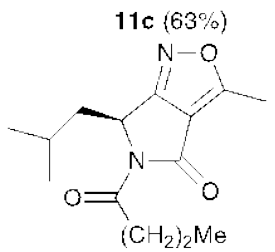<smiles>CC(=O)N1C(=O)c2c(noc2C)[C@@H]1CC(C)C</smiles><smiles>C=CC(=O)N1C(=O)c2oc(C)nc2[C@H]1CC(C)C</smiles><smiles>CC(C)=O</smiles>

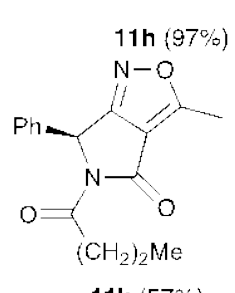<smiles></smiles>

55 This completed the synthesis of the reutericyclin analogues. Next we determined to create some tetramide analogues, by $\mathrm{N}-\mathrm{O}$ bond cleavage of the pyrroloisoxazole nucleus. This was achieved for bicycles 11a,f by hydrogenolysis ( 1 atm $\mathrm{H}_{2}, \mathrm{Pd}-\mathrm{C}$ ) to afford the enaminoketones (tetramides) 12a,b (49 and 52\%) 60 (Scheme 4). To demonstrate an alternative protocol, and because hydrogenation would be likely to reduce an unsaturated $\mathrm{N}$-acyl group, ${ }^{10 \mathrm{~b}} \mathrm{~N}-\mathrm{O}$ cleavage of $\mathbf{1 1 l}$ was accomplished by $\mathrm{Mo}(\mathrm{CO})_{6}$ (aq. $\mathrm{MeCN}$; then $2 \mathrm{M}$ aq. $\mathrm{HCl}$ ) to give enaminoketone 12c $(60 \%){ }^{16}$ Attempted hydrolysis of the enamine to generate 65 acyltetramic acid either returned unchanged enaminoketone (e.g. $\mathrm{H}_{2} \mathrm{O}$ at $20{ }^{\circ} \mathrm{C}$ or $2 \mathrm{M}$ aq. $\mathrm{HCl}$ at reflux; $\mathrm{NaNO}_{2}$, $3 \mathrm{M}$ aq. $\mathrm{H}_{2} \mathrm{SO}_{4}$ ) or led to $\mathrm{N}$-deacylation (aq. $\mathrm{NaOH}, 2 \mathrm{M}$ at reflux or $0.1 \mathrm{M}$ at $20^{\circ} \mathrm{C}$ ). 


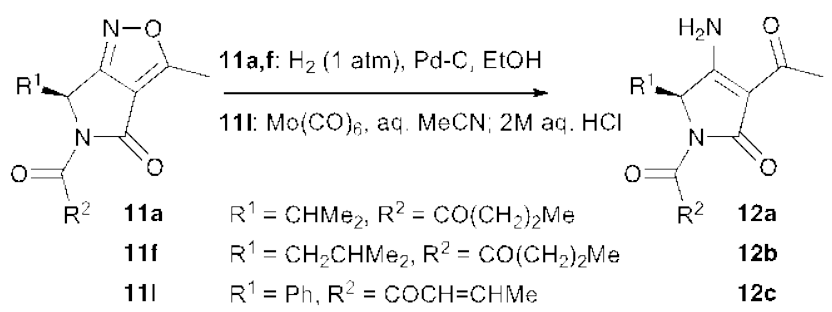

Scheme 4. Formation of $\mathrm{N}$-acyltetramides $\mathbf{1 2}$ from pyrroloisoxazoles $\mathbf{1 1}$

In conclusion, we have developed a synthetic route, based on a nitrone 1,3-dipolar cycloaddition, from amino acids to $\mathrm{N}$ 5 acylpyrrolo[3,4-c]isoxazoles $\mathbf{1 1}$ as reutericyclin analogues, and presented a diverse selection of 12 novel compounds. Furthermore, we have demonstrated the conversion of these heterobicycles into $\mathrm{N}$-acyltetramides 12. All of these new compounds are currently undergoing biological evaluation.

10 The authors acknowledge Loughborough University for the award of studentships (C. C. M. L and J. P. B.) and Novartis for financial support (C. C. M. L.).

\section{Notes and references}

a Department of Chemistry, Loughborough University, Leics. LE11 3TU, 15 UK. Fax: +441509 223926; Tel: +44 1509 222557; E-mail:

r.c.f.jones@lboro.ac.uk

$\dagger$ Typical procedure for $\mathrm{N}$-acylpyrrolo[3,4-c]isoxazole formation: (S)-5Butyryl-6-isopropyl-3-methyl-5,6-dihydro-4H-pyrrolo[3,4-c]isoxazol-4-

one 11a. (S)-6-(1-Methylethyl)-3-methyl-5,6-dihydro-4H-pyrrolo[3,4$20 \mathrm{c}$ ]isoxazol-4-one 10a $(50.0 \mathrm{mg}, 0.277 \mathrm{mmol})$ was suspended in dry THF (20 mL) stirred at $-78{ }^{\circ} \mathrm{C}$ under a nitrogen atmosphere. n-Butyl-lithium ( $0.201 \mathrm{~mL}, 1.41 \mathrm{M}$ in hexanes, $0.283 \mathrm{mmol}$ ) was added and the reaction stirred for $15 \mathrm{~min}$ at this temperature, during which time the solution turned yellow. Butanoyl chloride ( $29.6 \mathrm{mg}, 27.0 \mu \mathrm{L}, 0.283 \mathrm{mmol}$ ) was

25 then added in two portions over $10 \mathrm{~min}$ and the mixture stirred at $-78{ }^{\circ} \mathrm{C}$ for a further $3 \mathrm{~h}$ before quenching by addition of satd. $\mathrm{NH}_{4} \mathrm{Cl}$ solution. The mixture was tested for $\mathrm{pH}$ to ensure neutrality had been achieved and then separated between water $(20 \mathrm{~mL})$ and EtOAc $(25 \mathrm{~mL})$. The organic layer was dried over $\mathrm{MgSO}_{4}$, filtered and concentrated under reduced 30 pressure to produce the title compound 11a as a yellow oil (62 mg, 89\%); $[\alpha]_{\mathrm{D}}^{20}+36.0\left(\right.$ c $\left.5.00 \times 10^{-3}, \mathrm{CHCl}_{3}\right) ; v_{\max }\left(\mathrm{CHCl}_{3}\right) / \mathrm{cm}^{-1} 3025,1725(\mathrm{C}=\mathrm{O})$, 1689 (C=O), 1650, 1389, 1250, 1131; $\delta_{\mathrm{H}}\left(400 \mathrm{MHz} ; \mathrm{CDCl}_{3}\right) 0.50$ (3H, d, $J$ $\left.=6.8, \mathrm{CH}\left(\mathrm{CH}_{3}\right)_{2}\right) 0.92\left(3 \mathrm{H}, \mathrm{t}, J=7.2, \mathrm{CH}_{2} \mathrm{CH}_{3}\right), 1.17(3 \mathrm{H}, \mathrm{d}, J=6.8$, $\left.\mathrm{CH}\left(\mathrm{CH}_{3}\right)_{2}\right), 1.55-1.61\left(2 \mathrm{H}, \mathrm{m}, \mathrm{CH}_{2} \mathrm{CH}_{3}\right), 2.61\left(3 \mathrm{H}, \mathrm{s}, 3-\mathrm{CH}_{3}\right), 2.68-2.72$ $35\left(1 \mathrm{H}, \mathrm{m}, \mathrm{CH}\left(\mathrm{CH}_{3}\right)_{2}\right), 2.81,2.92$ (each $\left.1 \mathrm{H}, \mathrm{dt}, J=7.6,14.8, \mathrm{CH}_{2} \mathrm{CO}\right), 5.13$ $(1 \mathrm{H}, \mathrm{d}, J=4, \mathrm{CHN}) ; \delta_{\mathrm{C}}\left(100 \mathrm{MHz} ; \mathrm{CDCl}_{3}\right) 11.8,12.8,13.1\left(\mathrm{CH}_{3}\right), 17.0$ $\left(\mathrm{CH}_{2} \mathrm{CH}_{3}\right)$, $17.9\left(\mathrm{CH}_{3}\right), 27.0\left(\mathrm{CH}\left(\mathrm{CH}_{3}\right)_{2}\right), 38.2\left(\mathrm{CH}_{2} \mathrm{CO}\right), 59.9(\mathrm{CHN})$, 113.0, 159.5, 165.0 (Isoxazole-C), 168.6, 173.2 (CO). HRMS (ESI): $\mathrm{MNa}^{+}$273.1211; $\mathrm{C}_{13} \mathrm{H}_{18} \mathrm{~N}_{2} \mathrm{O}_{3}$ requires $\mathrm{MNa}^{+}$273.1210.

$40 \ddagger$ Crystal data for 11c: $\mathrm{C}_{13} \mathrm{H}_{16} \mathrm{~N}_{2} \mathrm{O}_{3}, M=248.28$, orthorhombic, $P 2{ }_{1} 2_{1} 2_{1}, a$ $=6.9698$ (12), $b=9.5108$ (16), $c=19.233$ (3) $\AA, V=1274.9$ (4) $\AA^{3}, Z=$ $4, \mu(\mathrm{Mo}-\mathrm{K} \alpha)=0.71073 \AA, 11350$ reflections measured at $150 \mathrm{~K}$ on a Bruker APEX 2 CCD diffractometer, 2618 unique data, $R_{\text {int }}=0.034, R[$ for 2390 data with $\left.F^{2}>2 \sigma\left(F^{2}\right)\right]=0.032, w R_{2}$ (all data) $=0.078,227$

45 parameters. $\mathrm{H}$ atoms were freely refined. Absolute structure $\{\mathrm{x}=0.0(6)\}$ could not be determined reliably. CCDC 959645.

1 For example: World Health Organisation, Fact Sheet no. 194, May 2013, http://www.who.int/mediacentre/factsheets/fs194/en/, accessed 09 Aug 2013. U. Theuretzbacher and J. H. Toney, Curr. Opin. Invest. Drugs, 2006, 7, 158-66.

2 A. Holtzel, M. G. Ganzle, G. J. Nicholson, W. P. Hammes and G. Jung, Angew. Chem., Int. Ed., 2000, 39, 2766-2768.

3 B. J. L. Royles, Chem. Rev., 1995, 95, 1981-2001. R. Schobert and A. Schlenk, Bioorg. Med. Chem., 2008, 16, 4203-21. Y.-C.Jeong and M. G. Moloney, J. Org. Chem. 2011, 76, 1342-1354.

4 For leading references: T. Sengoku, Y. Nagae, Y. Ujihara, M. Takahashi and H. Yoda, J. Org. Chem., 2012, 77, 4391-4401. Y.-C.
Jeong, M. Anwar, Z. Bikadi, E. Hazai and M. G. Moloney, Chem. Sci., 2013, 4, 1008-1015.

605 Kaufmann, G. F.; Sartorio, R.; Lee, S.-H.; Rogers, C. J.; Meijler, M. M.; Moss, J. A.; Clapham, B.; Brogan, A. P.; Dickerson, T. J.; Janda, K. D. Proc. Natl. Acad. Sci. U.S.A. 2005, 102, 309. Lowery, C. A.; Park, J.; Gloeckner, C.; Meijler, M. M.; Mueller, R. S.; Boshoff, H. I.; Ulrich, R. L.; Barry, C. E.; Bartlett, D. H.; Kravchenko, V. V.;

65 Kaufmann, G. F.; Janda, K. D. J. Am. Chem. Soc. 2009, 131, 14473. Ueda, C.; Tateda, K.; Horikawa, M.; Kimura, S.; Ishii, Y.; Nomura, K.; Yamada, K.; Suematsu, T.; Inoue, Y.; Ishiguro, M.; Miyairi, S.; Yamaguchi, K. Antimicrob. Agents Chemother. 2010, 54, 683.

6 R. Yendapally, J. G. Hurdle, E. I. Carson, R. B. Lee, and R. E. Lee, J. 70 Med. Chem., 2008, 51, 1487-91. M. G. Gänzle and R. F. Vogel, Appl Environ Microbiol., 2003 69, 1305-1307. M. G. Gänzle, Appl. Microbiol. Biotechnol., 2004, 64, 326-32.

7 C. Ueda, K. Tateda, M. Horikawa, S. Kimura, Y. Ishii, K. Nomura, K. Yamada, T. Suematsu, Y. Inoue, M. Ishiguro, S. Miyairi, and K. Yamaguchi, Antimicrob. Agents Chemother., 2010, 54, 683-688. J. G. Hurdle, A. E. Heathcott, L. Yang, B. Yan and R. E. Lee, J. Antimicrob. Chemother., 2011, 6, 1773-1776.

8 For leading references to our early pre-isoxazole work: R. C. F. Jones and M. Tankard, J. Chem. Soc., Perkin Trans. 1, 1991, 240-241. R.

$80 \quad$ C. F. Jones, G. Bhalay, J. M. Patience and P. Patel, J. Chem. Res. (S) 1999, 250-251.

9 For our related work on the 3-acyl-4-hydroxypyridin-2-one series: $\mathrm{R}$. C. F. Jones, A. K. Choudhury, J. N. Iley, M. E. Light, G. Loizou and T. A. Pillainayagam, Beilstein J. Org. Chem., 2012, 8, 308-312, and refs. therein.

10 For our 2nd generation approach: (a) R. C. F. Jones, C. E. Dawson, M. J. O’Mahony, Synlett, 1999, 873-876. (b) R. C. F. Jones and T. A. Pillainayagam, Synlett, 2004, 2815-2817. (c) R. C. F. Jones, C. C. M. Law and M. R. J. Elsegood, ARKIVOC 2013, (iii), 81-97.

9011 For our $1^{\text {st }}$ generation approach: R. C. F. Jones, G. Bhalay, P. A. Carter, K. A. M. Duller and S. H. Dunn, J. Chem. Soc., Perkin Trans. 1, 1999, 765-776, and refs. therein.

12 Cf. L. M Halo, J. M. Marshall, A. A. Yakasai, Z. Song, C. P. Butts, M. P. Crump, M. Heneghan, A. M. Bailey, T. J. Simpson, C. M.

95 Lazarus and R. J. Cox, ChemBioChem, 2008, 9, 585-594. L. M. Halo, M. N. Heneghan, A. A. Yakasai, Z. Song, K. Williams, A. M. Bailey, R. J. Cox, C. M. Lazarus and T. J. Simpson, J. Am. Chem. Soc., 2008, 130, 17988-17996.

13 For an enantiospecfific synthesis of reutericyclin via the Dieckmann 100 strategy: R. Böhme, G. Jung and E. Breitmaier, Helv. Chim. Acta, 2005, 88, 2837-2841.

14 For a survey of coupling reagents: P. D. Bailey in Comprehensive Functional Group Transformations, eds. A. R. Katritzky and R. J. K. Taylor, Elsevier, Oxford, 2005, Vol. 5, p.221-225.

10515 A. L. L. García, Synlett, 2007, 1328-1329. H. Wissman and H.-J. Kleiner, Angew. Chem., Int. Ed., 1980, 133-134.

16 M. Nitta and T. Kobayashi, J. Chem. Soc., Perkin Trans. 1, 1985, 1401-1406. 